\title{
Analysis of Cambodia's macroeconomic development
}

\author{
Qiming Tang ${ }^{1}$, Meijuan $\mathrm{Li}^{* 1}$ (Corresponding Author) \\ ${ }^{1}$ Yunnan Normal University, Kunming, China \\ Corresponding Author: Meijuan Li
}

\begin{abstract}
From 2012 to 2018, the annual GDP growth rate of Cambodia exceeded 7\%, maintaining rapid development for 7 consecutive years, and it is one of the fastest economic growth rates among developing countries in Asia in recent years. The overall unemployment rate is low, the inflation is moderate and controllable, the trade deficit between import and export, the net inflow of foreign direct investment is increasing by years, and the foreign exchange reserve is growing steadily. In the future, the macro economy of Cambodia will continue to maintain a strong growth momentum.
\end{abstract}

\section{Introduction}

The kingdom of Cambodia is located on Indochina peninsula, bordering Thailand in the west and northwest, Laos in the northeast, and Vietnam in the east and southeast. The area is about 180,000 square kilometers. It has a population of about 15 million, $80 \%$ of whom are Khmer. There are about one million overseas Chinese ${ }^{[1]}$. Cambodia is rich in natural resources. The central part of Cambodia is a vast and rich plain, accounting for more than three quarters of the country. It is a major riceproducing country in the world. Forest coverage is $61.4 \%$. Rich in gold, copper, iron, zinc, lead, sapphire, ruby and other mineral resources, especially in recent years, Cambodia has discovered a series of mineral deposits with considerable reserves ${ }^{[2]}$. The government of Cambodia has implemented an open free market economy, carried out economic privatization and trade liberalization, and given priority to agriculture, processing industry, tourism, infrastructure construction and personnel training. As a result, the economy of Cambodia has developed rapidly.

In 1999, Cambodia joined the association of southeast Asian nations (asean). In 2001, Cambodia began the reform of the market economy system. In 2004, Cambodia joined the world trade organization (wto). The state implements a highly free and open free market economic policy and promotes privatization and trade liberalization. Agriculture and tourism are two pillar industries. Cambodia is the world's fifth largest rice producer. Cambodia has outstanding advantages in agricultural development. It has many advantages such as abundant land resources, less natural disasters and low labor costs. The per capita cultivated land area is more than $6 \mathrm{mu}(4$ mu per capita cultivated land area in the world, $1.2 \mathrm{mu}$ per capita cultivated land area in China), and the available cultivated land area is about 6.7 million hectares, the cultivated land rate is less than $40 \%$, and there are still 4 million hectares to be developed. However, Cambodia's agricultural development is also facing serious problems of backward technology, inadequate infrastructure and low added value of products. Tourism accounts for more than $10 \%$ of GDP, and related industries driven by tourism contribute nearly $40 \%$ of GDP, making it one of the countries with the highest proportion of tourism in GDP in Asia.

China and Cambodia enjoy a time-honored traditional friendship and frequent high-level exchanges. The two countries officially established diplomatic ties on July 19, 1958. Over the years, several generations of Chinese leaders have established profound friendship with former king Sihanouk, laying a solid foundation for the long-term stable development of bilateral relations. During prime minister Sen Hong's visit to China in December 2010, the two countries announced the establishment of a comprehensive strategic cooperative partnership ${ }^{[3]}$. The two countries have maintained close exchanges and cooperation in political parties, parliaments, military affairs, culture and education. The two sides have signed the china-cambodia agreement on cultural cooperation, the agreement on mutual exemption of visas for diplomatic and official passport holders and the memorandum of understanding on cooperation in the fields of cultural relics protection, tourism, police, sports, agriculture, water conservancy, construction and land and resources management.

China and Cambodia enjoy close economic and trade exchanges. China is Cambodia's largest trading partner and largest source of foreign investment. According to the Cambodia development council (CDC), China's total investment in Cambodia reached $\$ 3.6$ billion in 2018, accounting for 53 percent of total foreign investment in the country, an increase of 54 percent from 2017. In 2017, bilateral trade reached us $\$ 6$ billion, and the two countries have reached the target of us $\$ 10$ billion in bilateral trade by $2023^{[4]}$. More than 45 percent of Cambodia's national 
highways are built by Chinese enterprises, and the longest fiber optic cable and the first international submarine fiber optic cable are also built by China. Seven of the 12 Bridges built by foreign investment in Cambodia are under Chinese investment and construction ${ }^{[5]}$. The two sides will work together to deepen cooperation under the "One Belt And One Road" framework, which will not only promote the development of the china-indochina peninsula economic corridor, but also provide important support for the 21 st century maritime silk road to extend to the Indian Ocean and the south Pacific ${ }^{[6]}$. At the same time, Cambodia's development weaknesses in infrastructure construction and other areas coincide with the "One Belt And One Road" opportunity. The two countries have broad space for cooperation in irrigation and water conservancy, communications, energy transportation and industrial transformation and upgrading.

This paper mainly analyzes the macroeconomic development of Cambodia in recent years from the aspects of economic growth, unemployment rate, price level, import and export trade, foreign investment, international balance of payments and so on.

\section{Economic growth}

Cambodia's economy is growing fast, and it is one of the fastest growing countries in developing Asia in recent years $^{[7]}$. The rapid growth of Cambodia's economy is mainly due to the growth of clothing and footwear exports, real estate construction, service industry and agriculture, and increased government spending. It can be seen from table 1 that there is a growing tendency of the total GDP of Cambodia from 2012 to 2018, increasing from $\$ 14.1$ billion in 2012 to $\$ 24.6$ billion in $2018^{[8]}$. Over the past six years, the GDP has increased by 10.5 billion. In particular, the biggest increase was in 2017-2018, with an increase of \$2.4 billion in one year. From 2012 to 2018, the GDP per capita also increased by years, from $\$ 950.9$ in 2012 to $\$ 1,512.1$ in 2018 , it increases by an average of $\$ 93.50$ per year. Despite this, Cambodia is still relatively poor, the GDP per capita of $\$ 1,512.1$ in 2018, far below the world bank's standard of $\$ 3,895$ for lower-middleincome countries and is promising.

From 2012 to 2018, the annual GDP growth rate of Cambodia has exceeded $7 \%$, and the country has maintained rapid development for 7 consecutive years. In 2018, Cambodia's GDP growth rate was about 7.52\%, 0.5\% points higher than that of 2017. On the demand side, the growth rate of net exports showed positive growth again, while the growth rate of consumption and investment declined slightly. Calculated on the demand side, GDP growth in 2017, consumption, investment and export growth all declined slightly ${ }^{[8]}$. On the supply side, among the GDP growth in 2017, the growth rate of agriculture, fishery and forestry increased slightly, the growth rate of industry decreased slightly, and the growth rate of the service industry remained stable.
Table1. economic growth data of Cambodia

\begin{tabular}{|c|c|c|c|}
\hline year & $\begin{array}{c}\text { GDP } \\
\mathbf{( \$ 1 0 0} \\
\text { million) }\end{array}$ & $\begin{array}{c}\text { GDP per } \\
\text { capita(dollar) }\end{array}$ & $\begin{array}{c}\text { GDP } \\
\text { growth rate } \\
(\%)\end{array}$ \\
\hline 2012 & 141 & 950.9 & 7.31 \\
\hline 2013 & 152 & 1013.4 & 7.36 \\
\hline 2014 & 167 & 1093.5 & 7.14 \\
\hline 2015 & 180 & 1162.9 & 7.04 \\
\hline 2016 & 200 & 1269.6 & 7.03 \\
\hline 2017 & 222 & 1385.3 & 7.02 \\
\hline 2018 & 246 & 1512.1 & 7.52 \\
\hline
\end{tabular}

\section{Unemployment rate}

Cambodia's unemployment rate is generally low, remaining around $0.20 \%$ from 2014 to 2017 . The unemployment rate was the highest in $2013(0.30 \%)$, the lowest in 2014 and $2015(0.18 \%$ ), and $0.22 \%$ in 2017 (As shown in figure 1). Lower unemployment rate provides a guarantee for Cambodia's economic growth.

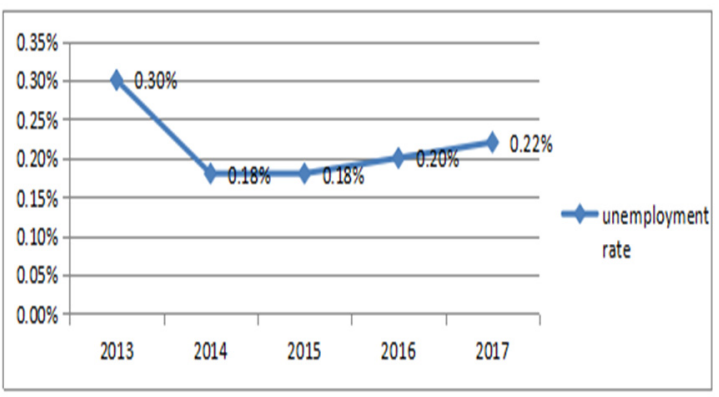

Fig1. changes of unemployment rate in Cambodia from 2013 to 2017

Source: Wind database

\section{Price level}

Inflation in Cambodia is moderate and controllable, and will remain low in the future. According to figure 2, it shows that from 2009 to 2017, the year-on-year CPI growth rate of Cambodia was relatively stable and the price level was low. From 2013 to 2017, the inflation rate in Cambodia remained in the range of $1.0 \%$ to $6.0 \%$, with a peak of $5.5 \%$ in 2011 . The average inflation rate was $3.3 \%$, which was moderate and relatively moderate ${ }^{[9]}$. Inflation rate averaged $2.4 \%$ in the first half of 2018 , down from $3.4 \%$ in the same period in 2017 , as food prices rose slightly. And the IMF expects inflation rate to remain at $3.3 \%$ in 2018-19. In October 2018, the year-on-year growth rate of both the overall CPI and the core CPI in Cambodia increased. In February 2019, food and nonalcoholic beverages, among others, contributed the most to Cambodia's month-on-month CPI growth. 


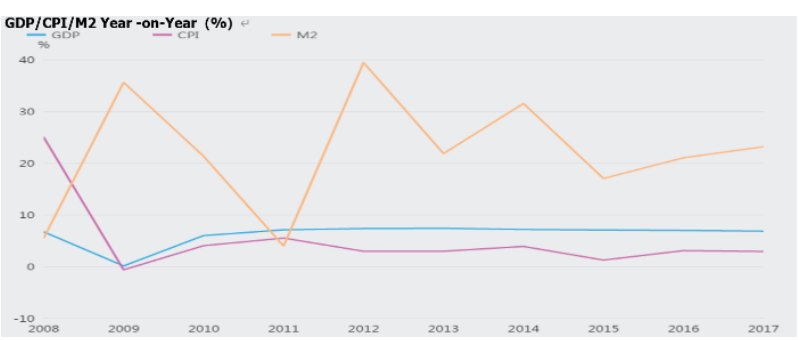

Fig2. changes in year-on-year CPI growth in Cambodia from 2008 to 2017

\section{Import and export trade}

From 2000 to 2018, Cambodia's total export volume increased by years, mainly due to the garment industry, agriculture and industrial products, trade export markets have grown to 147 countries $^{[10]}$. Cambodia imports more than it exports, and has run a trade deficit in recent years, as shown in figure 3. In 2018, Cambodia's total imports and exports volume reached $\$ 24.985$ billion, with $\$ 11.214$ billion in exports and $\$ 13.771$ billion in imports, resulting in a trade deficit of $\$ 2.557$ billion, up $4.05 \%$ from $\$ 2.242$ billion in 2017 ${ }^{[11]}$. In February 2019, Cambodia's monthly trade surplus was $\$ 51.6$ million. Monthly export growth was 9\%, down slightly from January. Monthly import growth was $-25 \$$, down sharply from January.

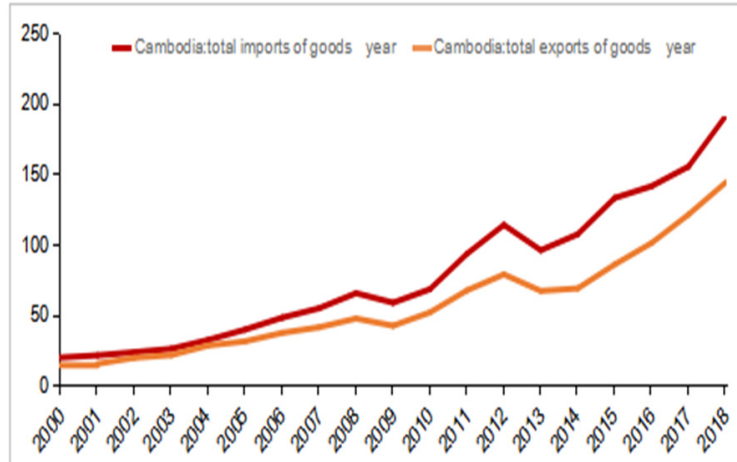

Fig3. Cambodia's import and export trade in 2000-2018 ( $\$ 100$ million)

Source: Wind database

China is currently Cambodia's largest trading partner. Since the establishment of diplomatic ties on July 19, 1958, bilateral trade has gradually expanded. Currently, China is the largest importer of Cambodian rice ${ }^{[12]}$. In 2016, when Cambodia's rice exports suffered and farmers' living standards were threatened, China actively increased rice imports to Cambodia, relieves the urgent need of its agricultural field. China is also the largest source of tourists to Cambodia. In the past two years, Chinese tourists ranked the first among international tourists to Cambodia. According to a report by Cambodia's tourism ministry, said that about 1.2 million Chinese tourists visited Cambodia in 2017, accounting for $21 \%$ of the total number of foreign tourists, up $46 \%$ year on year and overtaking Vietnam for the first time as the largest source of tourists to Cambodia ${ }^{[13]}$. By 2019, Cambodia has built a series of infrastructure projects supported by China and will continue to stimulate demand for capital and intermediate imports in 2019-2023.At the same time, merchandise exports in the first five months of 2019 rose $14 \%$ from a year earlier, mainly due to strong demand from the apparel and tourism sectors, particularly from the United States. According to the latest figures, the forecast for export growth in 2019 was revised up to $9.8 \%$ from $8.7 \%$ previously. Exports will continue to grow, led by a modest recovery in clothing and increased shipments of other goods, such as bicycles. Moreover, the growth of imports will continue to outpace the growth of exports, leading to a large imbalance in trade in goods.

\section{Foreign direct investment}

Cambodia's fast-growing economy has attracted foreign direct investors. From figure 4, it can be seen that from 2000 to 2018, the net inflow of foreign direct investment in Cambodia increased by years, especially after 2009, the annual net inflow of foreign direct investment increased significantly ${ }^{[14]}$. At present, China is the largest source of foreign investment in Cambodia. According to data released by the Cambodian development council (CDC), China's investment in Cambodia reached $\$ 1.431$ billion in 2017, ranking first, mainly in large-scale projects such as hydropower and leisure development ${ }^{[15]}$. With the assistance of China, the construction of public facilities in Cambodia has developed rapidly and the quality of life of the residents has been greatly improved

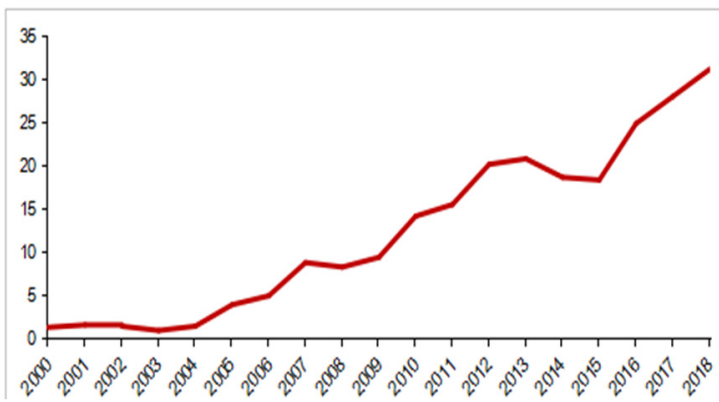

Fig4. net inflow of foreign direct investment in Cambodia ( $\$ 100$ million)

Source: Wind database

\section{International balance of payment}

In terms of balance of payments, as shown in table 2, the current account of Cambodia was in deficit from 2013 to 2016. The current account deficit widened to $\$ 1.775$ billion in 2016 from $\$ 1.692$ billion in 2015 . Total reserves (including gold) are low, but are increasing by years, to $\$ 11.78$ billion in 2018. The Macroeconomic is stable and foreign exchange reserves are steadily increasing ${ }^{[16]}$. There is still considerable room for economic development and improvement in the future. Foreign exchange reserves rose to $\$ 11.26$ billion in 2017 which can be cover six months of imports of goods and services. According to the report by the Asian development bank, Cambodia's overall payment balance remained in surplus and its foreign exchange reserves increased in the first half 
of 2018 due to strong inflows of foreign direct investment. The service account surplus will continue to grow due to the arrival of foreign tourists, especially from China. But the projected expansion of the service account surplus will not be enough to offset the shortfall in the trade account, the current account deficit is forecast to average $10.6 \%$ of GDP in 2019-2023.

Table2. Cambodia's International balance of payment from 2013 to 2017 (\$100 million)

\begin{tabular}{|c|c|c|c|c|c|}
\hline & $\mathbf{2 0 1 3}$ & $\mathbf{2 0 1 4}$ & $\mathbf{2 0 1 5}$ & $\mathbf{2 0 1 6}$ & $\mathbf{2 0 1 7}$ \\
\hline $\begin{array}{c}\text { Current } \\
\text { account } \\
\text { balance }\end{array}$ & 19.84 & 16.40 & 16.92 & 17.75 & -- \\
\hline $\begin{array}{c}\text { Total } \\
\text { reserves } \\
\text { includi } \\
\text { ng gold) }\end{array}$ & 49.98 & 61.08 & 73.07 & 88.52 & 117.80 \\
\hline
\end{tabular}

\section{Conclusion}

On the whole, Cambodia's economy and employment are relatively stable. In the context of the global economic slowdown in 2018, the GDP growth rate reached the highest level in five years, demonstrating a strong driving force for economic growth. Affected by the trade friction between China and the United States, it is estimated that the industries transferred from China to Cambodia have an accelerating trend, which to some extent brings new opportunities for the economic development of Cambodia. Since 2019, Cambodia's exports of agricultural products and cash crops such as rubber to China have grown strongly, and the Cambodian economy will continue to maintain strong growth momentum.

\section{References}

1. Ye Fang. Economic and financial operation situation and prospect of Cambodia in the first half of 2019 [J]. Regional finance research, 2019 (08): 40-41.

2. World Economic Outlook, April 2019 Growth Slowdown, Precarious Recovery. IMF. https : //www.imf.org/en/Publications/WEO/Issues/2019/03 /28/world-economic-outlook-april-2019 . 2019.

3. Ma Li. Review of Cambodia's economic situation in 2018 and outlook for 2019 [J]. Financial economy, 2019 (12) : 124-126.

4. Wang Zhigang. High-growth miracle under open economy: an analysis of post-reconstruction Cambodian economy [J]. Southeast Asian studies, 2015, (4): 4-11.

5. Liu Yonggang. Years of economic growth above 7\%; Asean is recognized to have the least investment regulation; Real estate investment boom -- Cambodia: the Khmer rouge is a past and now a hot place for investment [J]. China economic weekly, 2015, (44) : 68-71.
6. Pei changhong. Highlights of the maritime silk road: analysis on the development of economic and trade relations between China and Cambodia $[\mathrm{J}]$. Think tank of finance and economics, 2019, (4) : 5-17.

7. Wang wen, liu dian. Cambodia: a new model of "One Belt And One Road" international cooperation - a field research report on the economy and future development of Cambodia [J]. Contemporary world, 2018, (1): 29-33.

8. Ma chenghao. Cambodia tourism investment environment and risk analysis -- based on the perspective of Chinese investment enterprises [J]. Modern economic information, 2016, (15): 357-358.

9. Tian yuan, wang zhifang, kong weisheng, qi xin, fan penghui, wu ning, xing yu. Cambodia's exportoriented economic development and china-cambodia economic and trade cooperation [J]. International economic cooperation, 2017, (06): 60-66.

10. Wang zhigang. High-growth miracle in an open economy: an economic analysis of postreconstruction Cambodia $[\mathrm{J}]$. Southeast Asian studies, 2015, (04): 4-11.

11. Cheng cheng, li xue, liu yaxin. Tertiary industry, factors of production and economic growth in Cambodia [J]. Journal of guangxi university (philosophy and social sciences), 2019, (4): 118-124.

12. Zheng guofu. An empirical study on the relationship between foreign trade, foreign investment, foreign aid and Cambodia's domestic economic growth [J]. Economic forum, 2014, (4): 163-166.

13. Ye fang. Economic and financial performance and prospects of Cambodia in the first quarter of 2019 [J]. Regional finance research, 2019, (6): 32-33.

14. Wang xiangshe. World bank: Cambodia achieved economic growth of $7.5 \%$ in 2018 , higher than expected $[\mathrm{J}]$. World tropical agriculture information, 2019, (5): 11-12.

15. SELA VISETH. Research on foreign direct investment and its influencing factors in Cambodia [J]. Contemporary economics, 2018, (6): 94-97.

16. Yang ming-guo, jin rui-ting. Analysis of the current economic situation in Cambodia and policy Suggestions on promoting china-cambodia bilateral cooperation $[\mathrm{J}]$. China economic and trade guide (theoretical edition), 2017, (17): 19-20. 